\title{
A Rare Cause of Subgaleal Hematoma in Children: Hair Pulling
}

\author{
Çocuklarda Subgaleal Hematomun Nadir Bir Nedeni: Saç Çekme
}

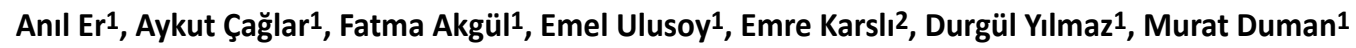 \\ ${ }_{1}$ Dokuz Eylül University Faculty of Medicine, Division of Pediatric Emergency Medicine, Izmir, Turkey \\ 2Dokuz Eylül University Faculty of Medicine, Department of Emergency Medicine, Izmir, Turkey
}

\section{Abstract}

Subgaleal hematoma is defined as blood collection within the loose areolar tissue of the scalp. The major cause of subgaleal hematoma in children is minor head trauma. It is characterized by diffuse scalp swelling crossing the suture lines which usually results in spontaneous recovery. Underlying coagulopathy should be evaluated in case of subgaleal hematoma after a trivial trauma. Another consideration for physicians, who face with a case of subgaleal hematoma, is complications such as proptosis, keratitis, and even airway compromise as a life-threatening event. Here, we present a case of uneventfully resolved subgaleal hematoma related with hair pulling.

Keywords: Hematoma, pediatric, scalp, trauma

\section{Introduction}

Subgaleal hematoma (SGH) is a well-known condition in neonates especially after prolonged or instrumental delivery, but it has been rarely reported in childhood. ${ }^{1-5}$ This condition is usually secondary to minor head trauma and an interesting mechanism of injury is hair pulling. ${ }^{3,4,6-8}$ In spite of its benign course, subgaleal hematomas may complicate by vision or lifethreatening events. ${ }^{6,8-11}$ In this paper, we present a case of uncomplicated SGH after hair pulling and aimed to describe its pathogenesis and management.

\section{Case}

An 8-year-old girl was admitted to the emergency department with progressive right scalp swelling and headache. She denied head trauma, but she explained that schoolmates had strongly pulled her hair 11 days ago. She had realized

\section{Öz}

Subgaleal hematom, saçlı derideki gevşek gözenekli dokuda kan birikimi olarak tanımlanmaktadır. Çocuklarda subgaleal hematomun en önemli nedeni hafif kafa travmasıdır. Saçlı deride sütür hatlarını geçen ve kendiliğinden gerileyen şişlik ile karakterizedir. Çocuklarda önemsiz travmalar sonrası gelişen subgaleal hematomlarda altta yatan koagülasyon bozukluğu varlığı araştırımalıdır. Bu olgularla karşılaşan hekimlerin dikkat etmesi gereken diğer bir nokta ise subgaleal hematomun propitozis, keratit ve hatta havayolu tıkanıklığı gibi yaşamı tehdit eden komplikasyonlardır. Burada komplikasyonsuz iyileşen saç çekmeye bağlı bir subgaleal hematom olgusu sunulmuştur. Anahtar Kelimeler: Hematom, pediyatrik, saçlı deri, travma

scalp swelling two days after hair pulling and headache has arisen next day. On initial assessment, vital signs were stable (heart rate: 84 beats per minute, respiratory rate: 18/min, blood pressure: 90/55mmHg) and Glasgow Coma Scale score was 15. Physical examination revealed a fluctuant and mildly tender scalp swelling extending from forehead to neck on the right side of the head. Extra-ocular muscle movements were intact and there was no proptosis or facial edema. Neurological evaluation was normal. Neither her medical history nor family history indicated any sign and symptom of coagulation disorders. Also, she did not take any medications such as acetylsalicylate. Complete blood count was normal with a hemoglobin level of $12.6 \mathrm{~g} / \mathrm{dL}$, hematocrit $37 \%$ and platelet $294.000 / \mathrm{mm}^{3}$. Aggregated thrombocytes were seen on peripheral blood smear microscopy. Prothrombin time and partial thromboplastin time were 12 seconds and 27 seconds, respectively. Computed tomography (CT) of the head showed diffuse subgaleal heterogeneous fluid collection without

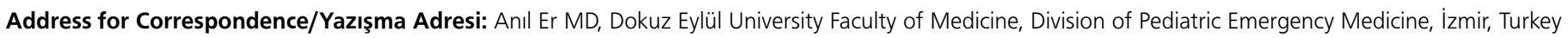
E-mail: anler.278@gmail.com

Received/Geliş Tarihi: 07.12.2016 Accepted/Kabul Tarihi: 06.01.2017

${ }^{\circ}$ Copyright 2017 by Society of Pediatric Emergency and Intensive Care Medicine

Journal of Pediatric Emergency and Pediatric Intensive Care published by Galenos Yayınevi. 
skull fracture (Figure 1). She was discharged after 4 hours of observation and acetaminophen was prescribed for headache.

On daily visits, she complained of a constant headache despite analgesic treatment. Also, we observed an increase in the size of scalp swelling which expanded to superior orbital rims and left parietal region by crossing the suture lines. There was no proptosis or facial edema again. Further laboratory evaluations revealed that bleeding time (3 minutes and 10 seconds), factor VIII, factor XIII, von Willebrand Factor antigen and function were normal. The hemoglobin level was $12.4 \mathrm{~g} / \mathrm{dL}$ without any significant decrease. Finally, SGH was resolved spontaneously after 3 weeks of follow-up.

\section{Discussion}

Scalp hematoma is a collection of blood arising from injured vessels. It is defined according to location and knowledge about anatomical structure is also essential for the comprehension of pathogenesis and management. Scalp is an acronym for skin, connective tissue, aponeurosis, loose areolar tissue and periosteum. ${ }^{4,6} \mathrm{SGH}$ is located in loose areolar tissue, between galea aponeurotica and periosteum. . $^{4,5}$ Loose areolar tissue includes a vast number of emissary veins that connects superficial scalp veins and subdural venous sinuses. Shearing or traction forces such as hair pulling lead to rupture of these veins and this space is wide enough to store large amounts of blood albeit limited with attachments of galea aponeurotica (orbital ridges, occipitofrontalis muscle and zygomatic arches). ${ }^{4,9,12}$ At this stage, SGH manifests with a fluctuant scalp swelling crossing the suture lines and patients usually complaint of headache, emesis, drowsiness or amnesia., ${ }^{4,910,13}$ It can be clinically distinguished from cephalohematoma that occurs in the periosteum. In contrast to SGH, cephalohematoma can not cross the suture lines typically as the periosteum is attached there. Another confusing diagnosis is caput succedaneum especially in neonates. Caput succedaneum is not limited by suture lines like SGH, but it contains less amount of seroanguinous fluid as develops in the connective tissue of the scalp., ${ }^{4,614}$ Although

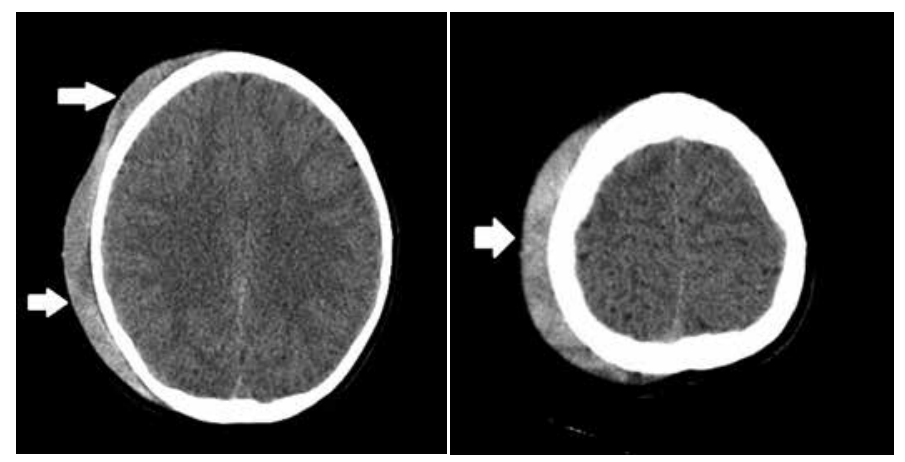

Figure 1. Computed tomography scan revealed diffuse subgaleal heterogenous fluid collection it is a clinical diagnosis, CT is useful for patients with suspicion of abuse or traumatic brain injury. ${ }^{7,15}$ Besides this, SGH can be the first manifestation of underlying coagulopathy such as von Willebrand disease and factor XIII deficiency. ${ }^{3,6,13}$ Therefore, physicians must be careful about history of easy bleeding or bruising and medications like salicylate. For the laboratory evaluation, Raffini and Tsarouhas ${ }^{3}$ suggested that complete blood count, prothrombin time and partial thromboplastin time are sufficient. However, we performed detailed laboratory tests considering increasing size of hematoma and ongoing complaints. During the course of the condition, SGH usually resolves spontaneously. But the blood in loose areolar tissue can pass beyond anatomic barriers of attachments and spread to orbita, face and neck with pressure and lead to proptosis, ophthalmoplegia, corneal ulceration, vision loss, facial edema or airway compromise. Treatment with aspiration and compressive bandage or surgical drainage has been reported in complicated hematoma. ${ }^{3,4,6,9,12}$ On the other hand, some authors suggested that invasive treatment is required only for extended or infected hematoma, hemodynamic instability, dural sinus injury or uncertain diagnosis of SGH suspicion of differential diagnosis on account of the fact that invasive procedures increase the infection risk. ${ }^{3,7}$ Thus, we preferred a conservative approach and the patient recovered uneventfully. In conclusion trivial trauma such as hair pulling can rarely lead to SGH in children and these patients should be evaluated for underlying coagulopathy. Spontaneous resolution is usually observed, but assessment of sight or life-threatening complications is essential in close follow-up.

\section{Ethics}

Informed Consent: The confirmation form was filled in by the families of all patients.

Peer-review: Internally peer-reviewed.

\section{Authorship Contributions}

Surgical and Medical Practices: A.E., E.K., Concept: A.E., E.U., Design: A.E., F.A., Data Collection or Processing: A.E., D.Y., Analysis or Interpretation: A.E., M.D., Literature Search: A.E., A.Ç., M.D., Writing: A.E.

Conflict of Interest: No conflict of interest was declared by the authors.

Financial Disclosure: The authors declared that this study received no financial support.

\section{References}

1. Kichari JR, Gielkens H. Massive traumatic subgaleal haematoma. Emerg Med J. 2013;30:344.

2. Meyer S, Gortner L, Abdul-Khaliq H, Papanagiotou P. Subgaleal hematoma. Indian J Pediatr. 2014;81:321. 
3. Raffini L, Tsarouhas N. Subgaleal hematoma from hair braiding leads to the diagnosis of von Willebrand disease. Pediatr Emerg Care. 2004;20:316-8.

4. Vu TT, Guerrera MF, Hamburger EK, Klein BL. Subgaleal hematoma from hair braiding: case report and literature review. Pediatr Emerg Care. 2004;20:821-3.

5. Amar AP, Aryan HE, Meltzer HS, Levy ML. Neonatal subgaleal hematoma causing brain compression: report of two cases and review of the literature. Neurosurgery. 2003;52:1470-4.

6. Kim D, Taragin B. Subgaleal hematoma presenting as a manifestation of Factor XIII deficiency. Pediatr Radiol. 2009;39:622-4.

7. Onyeama $\mathrm{CO}$, Lotke $\mathrm{M}$, Edelstein $\mathrm{B}$. Subgaleal hematoma secondary to hair braiding in a 31-month-old child. Pediatr Emerg Care. 2009;25:40-1.

8. Yip CC, McCulley TJ, Kersten RC, Kulwin DR. Proptosis after hair pulling. Ophthal Plast Reconstr Surg. 2003;19:154-5.

9. Pomeranz AJ, Ruttum MS, Harris GJ. Subgaleal hematoma with delayed proptosis and corneal ulceration. Ann Emerg Med. 1995;26:752-4.
10. Karcioglu ZA, Hoehn ME, Lin YP, Walsh J. Ocular involvement after subgaleal hematoma. J aapos. 2008;12:521-3.

11. Nichter LS, Bolton LL, Reinisch JF, Sloan GM. Massive subgaleal hematoma resulting in skin compromise and airway obstruction. J Trauma. 1988;28:1681-3.

12. Fujisawa $H$, Yonaha $H$, Oka $Y$, Uehara $M$, Nagata $Y$, et al. $A$ marked exophthalmos and corneal ulceration caused by delayed massive expansion of a subgaleal hematoma. Childs Nerv Syst. 2005;21:489-92.

13. Natarajan MS, Prabhu K, Braganza A, Chacko AG. Posttraumatic subgaleal and orbital hematoma due to factor XIII deficiency. J Neurosurg Pediatr. 2011;7:213-7.

14. Kuban K, Winston K, Bresnan M. Childhood subgaleal hematoma following minor head trauma. Am J Dis Child. 1983;137:637-40.

15. Hangai M, Kimura Y, Mori H, Yasui K, Tsuchida S, et al. Computed tomography findings of ongoing subgaleal hemorrhage. Pediatr Int. 2014;56:623-6. 